\title{
Stratigraphy of amethyst geode-bearing lavas and fault-block structures of the Entre Rios mining district, Paraná volcanic province, southern Brazil
}

\author{
LÉO A. HARTMANN, LUCAS M. ANTUNES and LEONARDO M. ROSENSTENGEL \\ Instituto de Geociências, Universidade Federal do Rio Grande do Sul, \\ Avenida Bento Gonçalves, 9500, Bairro Agronomia, 91501-970 Porto Alegre, RS, Brasil \\ Manuscript received on November 27, 2012, accepted for publication on October 8, 2013
}

\begin{abstract}
The Entre Rios mining district produces a large volume of amethyst geodes in underground mines and is part of the world class deposits in the Paraná volcanic province of South America. Two producing basalt flows are numbered 4 and 5 in the lava stratigraphy. A total of seven basalt flows and one rhyodacite flow are present in the district. At the base of the stratigraphy, beginning at the Chapecó river bed, two basalt flows are Esmeralda, low-Ti type. The third flow in the sequence is a rhyodacite, Chapecó type, Guarapuava subtype. Above the rhyodacite flow, four basalt flows are Pitanga, high-Ti type including the two mineralized flows; only the topmost basalt in the stratigraphy is a Paranapanema, intermediate-Ti type. Each individual flow is uniquely identified from its geochemical and gamma-spectrometric properties. The study of several sections in the district allowed for the identification of a fault-block structure. Blocks are elongated NW and the block on the west side of the fault was downthrown. This important structural characterization of the mining district will have significant consequences in the search for new amethyst geode deposits and in the understanding of the evolution of the Paraná volcanic province.
\end{abstract}

Key words: amethyst geode, Entre Rios mining district, Paraná volcanic province, geochemistry, gamma-spectrometry.

\section{INTRODUCTION}

The large-scale amethyst geode production (600 ton/month) from mines in the Paraná volcanic province, mostly Ametista do Sul (Brazil) and Los Catalanes (Uruguay) makes the understanding of the structure of mining districts a major topic in volcanic geology. The Entre Rios mining district in Santa Catarina, Brazil, has a large, unmeasured production of amethyst geodes. The establishment of lava stratigraphy and overall structure of the district is most significant for the discovery of

Correspondence to: Léo Afraneo Hartmann

E-mail: leo.hartmann@ufrgs.br new deposits. Only preliminary observations were previously made on the district (Juchem et al. 2010), so this is a novel contribution to the geology of the Entre Rios mining district with significant implications for the entire volcanic province.

The Paraná volcanic province is a major geological unit (Fig. 1) in southeastern South America $\left(917,000 \mathrm{~km}^{2}\right.$; Frank et al. 2009) and is composed of many (possibly 120) lava flows in each stratigraphic section. The rocks have varied bimodal compositions, mostly basalt and rhyodacite (e.g., Bellieni et al. 1984, Hartmann et al. 2010a, b) and are included in the Serra Geral 
Group. The volcanic group is near the top of the Paraná basin (Zalán et al. 1991) and the age of the rocks is close to $135 \mathrm{Ma}$ (e.g., Pinto et al. 2011, Janasi et al. 2011).

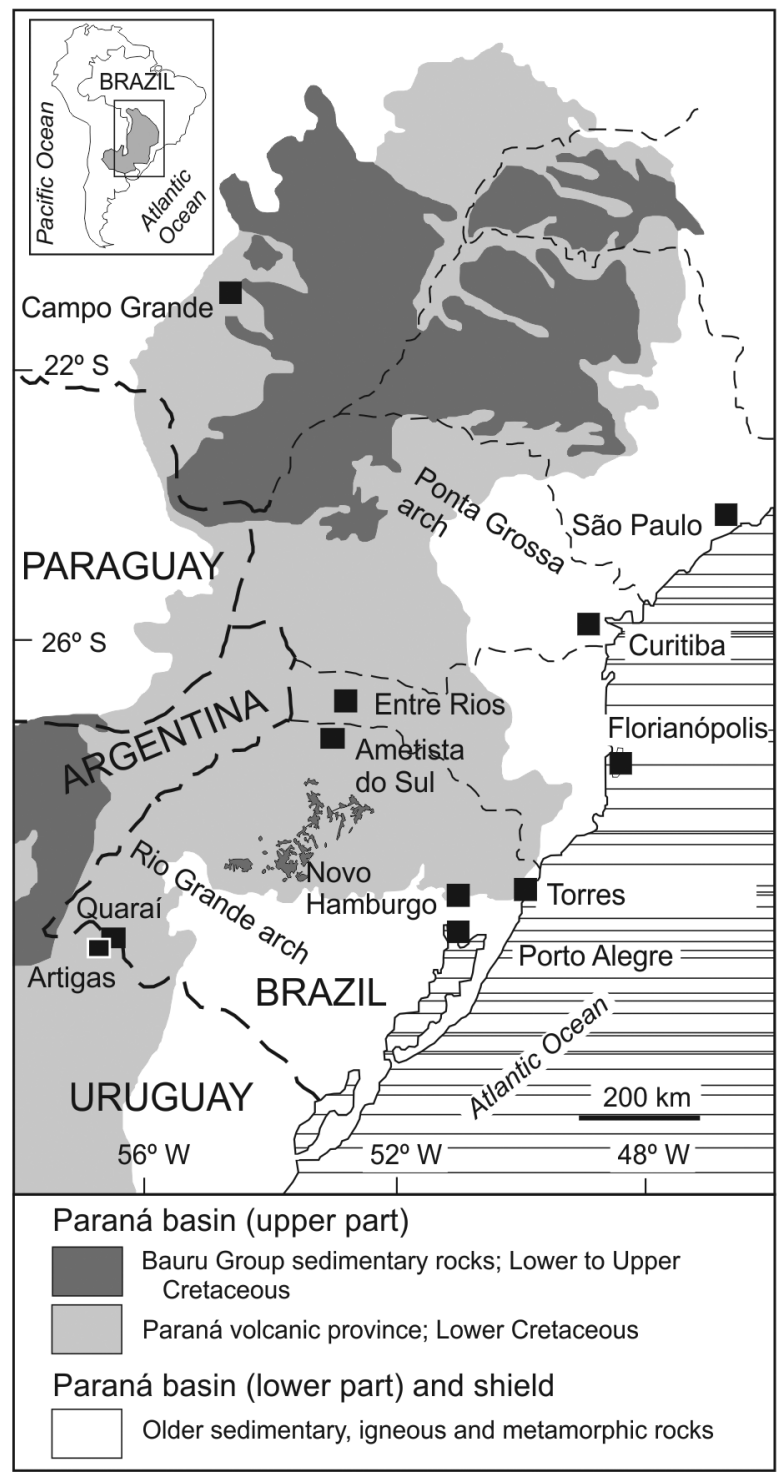

Figure 1 - Regional distribution of the Paraná volcanic province; location of Entre Rios town indicated.

Underground mining of amethyst and agate geodes occurs in basal andesite and basaltic andesite flows near the contact with the underlying Botucatu Formation eolian sandstones, e.g. Los Catalanes gemological district, Uruguay, but also in basalts situated $1,000 \mathrm{~m}$ above the contact with the sandstones, e.g. Ametista do Sul mining district, Brazil. The Entre Rios mining district (Fig. 2) is also approximately $1,000 \mathrm{~m}$ above the contact with the paleo-erg. The district is located in a transitional region between low-Ti basalt flows in the south and high-Ti flows in the north of the Paraná volcanic province (Bellieni et al. 1984, Peate et al. 1992). It is in the depocenter region of the Paraná basin (e.g., Arioli et al. 2008).

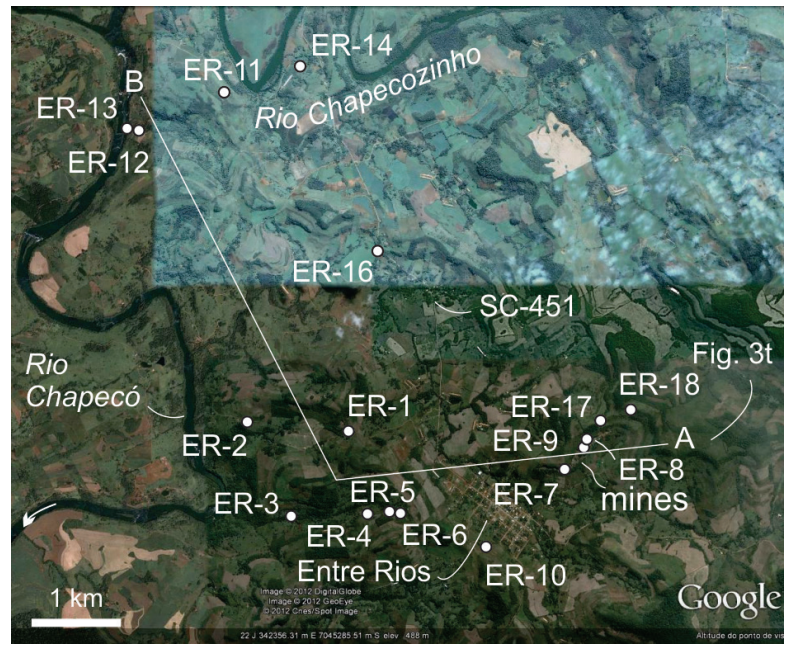

Figure 2 - Satellite image of the Entre Rios mining district. Location of geological section $(\mathrm{AB})$ and analyzed samples shown.

The Serra Geral Group differs from other continental flood basalt provinces due to its position above the Guarani aquifer (Araújo et al. 1999), which is contained in the Botucatu Formation. The fluid supersaturated in silica that caused the hydrotermal alteration, the formation of the silica gossan and the opening and filling of amethyst geodes, originated in this aquifer (Duarte et al. 2009, Hartmann et al. 2010a, b).

Previous studies in mineralized regions of the Paraná volcanic province led initially to the understanding that the protogeodes were formed by degassing of the basaltic lava at high temperature $\left(1,150^{\circ} \mathrm{C}\right)$, e.g. Gilg et al. (2003), Proust and Fontaine (2007) and Morteani et al. (2010). The observation that the basalts attained brittle conditions $\left(130^{\circ} \mathrm{C}\right)$ and were intensely altered to smectite and zeolites before 
the protogeode formation led to a more accurate hypothesis of low-temperature, epigenetic origin of the cavities (Duarte et al. 2009, 2011, Hartmann et al. 2012a, b, c), also supported by Commin-Fischer et al. (2010). The fluid that formed silica minerals in the geodes originated in the Guarani aquifer (Gilg et al. 2003). Only low-temperature (commonly $<80^{\circ} \mathrm{C}$ ) minerals are present in the geodes, as shown by oxygen isotopes (Juchem et al. 2010, Morteani et al. 2010, Duarte et al. 2011) and no epidote, chlorite or amphibole are known in the basaltic province, so higher temperature than $130^{\circ} \mathrm{C}$ should not be considered for the alteration and mineralization.

Volcanic rocks in the Entre Rios district are nearly horizontal, so the presence of vertical faulting is commonly overlooked. Evidence of large faults is readily seen in satellite images, but these are usually considered transcurrent, similar to the eastern border of the volcanic province (e.g. Jacques et al. 2010). The district of Entre Rios is located in the western region of the state of Santa Catarina, where the
Serra Geral Group is transitional between low-Ti basaltic flows in the south and the high-Ti flows in the northern portion of the group (Peate et al. 1992). The region has an elevation of up to $740 \mathrm{~m}$ above sea level (a.s.1.), with the base of the studied stratigraphy at $389 \mathrm{~m}$ along the Chapecó River bed. Only recently has the fault-block structure of the Ametista do Sul mining district (100 km to the south of Entre Rios) been recognized (Rosenstengel and Hartmann 2012). The investigation of the structure of mining districts and other portions of the Paraná volcanic province is most significant for the understanding of the processes responsible for the opening of the South Atlantic Ocean.

Sand injectites are observed in the Serra Geral Group, both in amethyst and agate geodemineralized and barren portions (Hartmann et al. $2012 \mathrm{c}, \mathrm{d})$. In spite of extensive weathering and soil cover of the studied region, silicified sand dikes in basalt and massive sandstones inside geodes are observed in the Entre Rios mining district (Fig. 3).

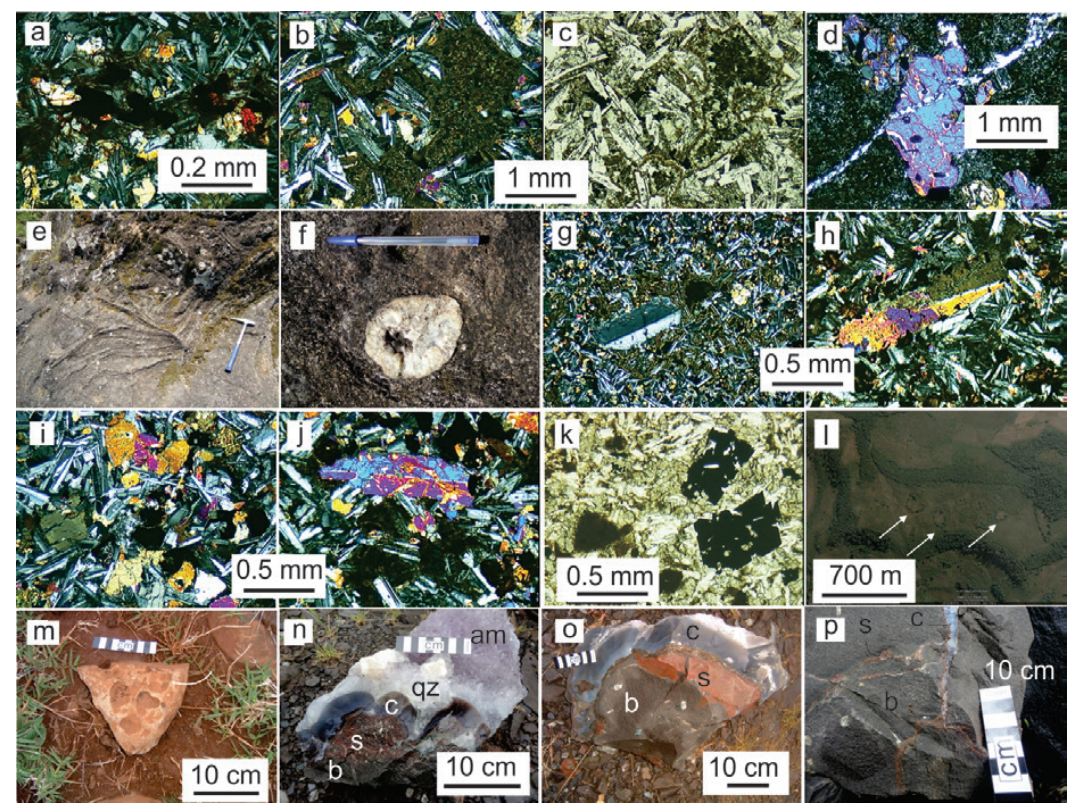

Figure 3 - Photomicrographs and field photos of the eight studied lava flows in the Entre Rios mining district. (a): flow 1; (b) and (c): flow 2; (d), (e) and (f): flow 3; (g): flow 4; (h): flow 5; (i): flow 6 (j): flow 7; (k): microphenocrysts of magnetite in flow 8; (l): satellite image of top of flow 8; arrows indicate gossans; (m): silicified basalt on top of flow 8; (n), (o): silicified sandstone in geodes of flow 5, showing a sequence of chalcedony, fine quartz, coarse quartz and amethyst; (p): sand dikes in flow 5 evolving to chalcedony along fracture. Symbols: $\mathrm{b}=$ basalt, $\mathrm{c}-$ chalcedony, $\mathrm{s}=$ silicified sandstone, $\mathrm{q}=$ quartz, am $=$ amethyst. 
We presently report field mapping, rock geochemistry and gamma-spectrometric emission rates of rocks and integrate this evidence to determine the local stratigraphy and overall district structure. The Entre Rios district in the state of Santa Catarina (Fig. 1) offers a rare opportunity for the study of the varied processes related to volcanism, hydrothermal alteration, sand injection, geode mineralization, lava stratigraphy and block-faulting in a context of a major continental flood basalt province.

\section{MATERIALS AND METHODS}

Previous investigations of mineralized and barren portions of the Paraná volcanic province were initially revised (e.g., Peate et al. 1992, Nardy et al. 2008, Duarte et al. 2009, 2011, Hartmann et al. 2010a, b, 2012a, b, c, d, Pinto and Hartmann et al. 2011, Pertille et al. 2013, Rosenstengel and Hartmann 2012). Field work followed satellite image study to determine the geological relationships of the lava flows, the amethyst geode mineralization and the faulting of the rocks in the district. In addition, the gamma-ray emission rate of the outcrops was measured with a portable gamma-ray spectrometer (Exploranium model GR110). Rock samples $(n=21)$ were collected (location in Fig. 2) for petrographic study and analyzed for their chemical composition in the ACME laboratory, Canada, using methods for groups $4 \mathrm{~A}$ and $4 \mathrm{~B}$.

\section{RESULTS}

The integrated use of field relationships, geochemistry and gamma-spectrometry led to the identification of the lava flows present, their stratigraphy and the overall fault-block structure of the mining district (Table I). Field and petrographic characterization support the proposed stratigraphic section.

TABLE I

Selected characteristics of the eight lava flows from the Entre Rios district. Flows 5 and 6 are mineralized in amethyst-geodes.

\begin{tabular}{|c|c|c|c|c|}
\hline Flow & Rock & $\begin{array}{l}\text { Chemical } \\
\text { type }\end{array}$ & $\begin{array}{l}\text { Thickness, } \\
\mathrm{m}\end{array}$ & Mineralogy \\
\hline 1 & Basalt & Esmeralda & 17 & $\begin{array}{l}\text { Aphanitic, holocristaline, composed mostly of } \\
\text { plagioclase and augite. Alteration to smectite. } \\
\text { Presence of hematite. }\end{array}$ \\
\hline 2 & Basalt & Esmeralda & 10 & $\begin{array}{l}\text { Aphanitic, holocristaline, composed mostly of } \\
\text { plagioclase and augite. Alteration to smectite. }\end{array}$ \\
\hline 3 & Rhyodacite & Chapecó & 65 & $\begin{array}{l}\text { Porphyritic with phenocrysts of plagioclase and } \\
\text { augite. Quartz geodes (size ranging from mm } \\
\text { to } \mathrm{cm} \text { ) and amygdales filled with celadonite. } \\
\text { Microcrystalline matrix intensely altered. }\end{array}$ \\
\hline 4 & Basalt & Pitanga & 15 & $\begin{array}{l}\text { Microporphyritic with phenocrysts of } \\
\text { plagioclase. Microcrystalline matrix composed } \\
\text { of plagioclase and augite. Intense alteration } \\
\text { to smectite and celadonite. Mineralized. }\end{array}$ \\
\hline 5 & Basalt & Pitanga & 15 & $\begin{array}{l}\text { Microporphyritic with phenocrysts and matrix of } \\
\text { zoned plagioclase. Microcrystalline matrix } \\
\text { composed of plagioclase and augite. } \\
\text { Alteration to smectite and celadonite. }\end{array}$ \\
\hline 6 & Basalt & Pitanga & 25 & $\begin{array}{c}\text { Microporphyritic with phenocrysts and } \\
\text { matrix of plagioclase and augite. } \\
\text { Alteration to smectite. Mineralized. }\end{array}$ \\
\hline 7 & Basalt & Pitanga & 40 & $\begin{array}{l}\text { Microporphyritic with phenocrysts and matrix of } \\
\text { plagioclase and augite. Alteration to smectite. }\end{array}$ \\
\hline 8 & Basalt & Paranapanema & 40 & $\begin{array}{l}\text { Aphanitic, holocrystalline; plagioclase } \\
\text { and clinopyroxene dominant. }\end{array}$ \\
\hline
\end{tabular}


The geochemical analysis of rocks was an essential tool for the characterization of lava flows in the mining district of Entre Rios (Fig. 4), because each flow has a characteristic concentration of major, minor and trace elements, mainly $\mathrm{TiO}_{2}, \mathrm{P}_{2} \mathrm{O}_{5}, \mathrm{MgO}$, $\mathrm{K}_{2} \mathrm{O}, \mathrm{Zr}, \mathrm{U}, \mathrm{Nb}, \mathrm{Sr}, \mathrm{Rb}, \mathrm{Th}$, and $\mathrm{Y}$ (Fig. 5). The geochemical composition indicates the presence of varied magma types in the district and an overall faultblock structure. Three contrasting basalt magma types (Peate et al. 1992) are present in the mining district, the low-Ti Esmeralda, the high-Ti Pitanga and the intermediate-Ti Paranapanema types, in addition to a Chapecó-type (Guarapuava subtype, Nardy et al. 2008) rhyodacite $\left(\mathrm{SiO}_{2} \sim 64.5\right.$ wt.\%). The overall stratigraphy includes eight flows with individual flow thicknesses estimated at 25-60 m. Basalt compositions in the seven flows range from $\mathrm{SiO}_{2}=44.35$ to 51.63 wt.\%. The amethyst geode mineralization occurs in two Pitanga-type flows (numbered 4 and 5; see Table II). Location and elevation of each analyzed sample are given in Table III.

The rhyodacite flow is an important stratigraphic marker in the district, because it is located at the top of the Esmeralda-type basalt flow 2 and therefore below four Pitanga-type basalt flows. A Paranapanema-type basalt occurs on top of the stratigraphic sequence.

The Esmeralda-type lavas have low silicon content $\left(\mathrm{SiO}_{2}=49.15\right.$ to 50.89 wt.\%), low Ti, $\mathrm{P}_{2} \mathrm{O}_{5}$ and $\mathrm{K}_{2} \mathrm{O}, \mathrm{Rb}, \mathrm{Sr}, \mathrm{Zr}, \mathrm{U}$, Th and $\mathrm{Nb}$. The highest $\mathrm{MgO}$ (7.1 wt.\%) occurs in lava 1, present in the Chapecó river bed, while $\mathrm{MgO}$ varies between 3-5 wt.\% in most basalts. Flow 5 has different characteristics from the other basalts, because it is enriched in most incompatible trace elements; e.g., $\mathrm{P}_{2} \mathrm{O}_{5}, \mathrm{Zr}, \mathrm{Rb}, \mathrm{U}$ and $\mathrm{Nb}$ (Fig. 5). As expected, the rhyodacite is much richer in $\mathrm{K}_{2} \mathrm{O}, \mathrm{Nb}, \mathrm{Rb}, \mathrm{Th}, \mathrm{U}$, $\mathrm{Zr}$, Y and $\mathrm{Sr}$ relative to the basalts.

The Pitanga-type basalts are geochemically similar but have small geochemical variations from flow to flow. Flow 4 (mineralized) has the lowest values of $\mathrm{SiO}_{2}$ (44.35 to 44.88 wt.\%), which is probably a result of hydrothermal alteration (LOI $>5$ wt.\%). It has the highest values of $\mathrm{TiO}_{2}, \mathrm{Sr}$ and $\mathrm{V}$, and the lowest $\mathrm{K}_{2} \mathrm{O}$ and $\mathrm{Rb}$. Flow 5 (also mineralized) is enriched in some elements in relation to the other Pitanga-type basalts, particularly $\mathrm{SiO}_{2}$ (50.83-51.63 wt.\%), $\mathrm{P}_{2} \mathrm{O}_{5}, \mathrm{~K}_{2} \mathrm{O}, \mathrm{Rb}$, Th, $\mathrm{Zr}$ and Y. Flow 6 is poorer in $\mathrm{TiO}_{2}, \mathrm{P}_{2} \mathrm{O}_{5}, \mathrm{Nb}, \mathrm{Rb}, \mathrm{Sr}$, Th, and $\mathrm{Zr}$, and slightly enriched in $\mathrm{MgO}$ and $\mathrm{CaO}$. Flow 7 has intermediate contents of many of the elements in relation to other Pitanga-type basalts. The Paranapanema-type basalt (flow 8) has intermediate composition between the depleted Esmeralda-type flows 1 and 2 and the enriched Pitanga-type flows 4, 5, 6 and 7.

Gamma-spectrometric readings are also characteristic of each flow and can be used as a field guide for the quick correlation of outcrops, particularly the continuous exposures of two or three different flows. The cps values are directly related to the contents of $\mathrm{K}_{2} \mathrm{O}, \mathrm{U}$ and $\mathrm{Th}$ of the rock (Fig. 6). The rhyodacite (flow 3) stands out at 135 cps, whereas the basalts vary from 35-80 cps.

The presence of silicified sand as dikes, sills and partly filling geodes seems to be a necessary requirement for the formation of the silica ore. The sand was probably injected 1,000 m upwards from the buried, non-lithified erg at the time of volcanism, in a process similar to the underground sand mobilization described from the North Sea offshore basins (Hurst et al. 2011).

The hydrothermal alteration of the rocks in the district is evidenced by the significant presence of smectite in all basalt flows, the occurrence of celadonite in mineralized basalts both filling amygdales and rimming amethyst geodes. Also, the presence of veins of silicified sandstones in mineralized basalt flows and the intense silicification in the flow of the hilltop are evidence for hydrothermal processes. Another evidence is the presence of hydrothermal breccia below flow 8 (Paranapanema, intermediate-Ti type), which has columnar jointing and displays the presence of hydrothermal breccias (Hartmann et al. 2010a, b) at the base. These factors 


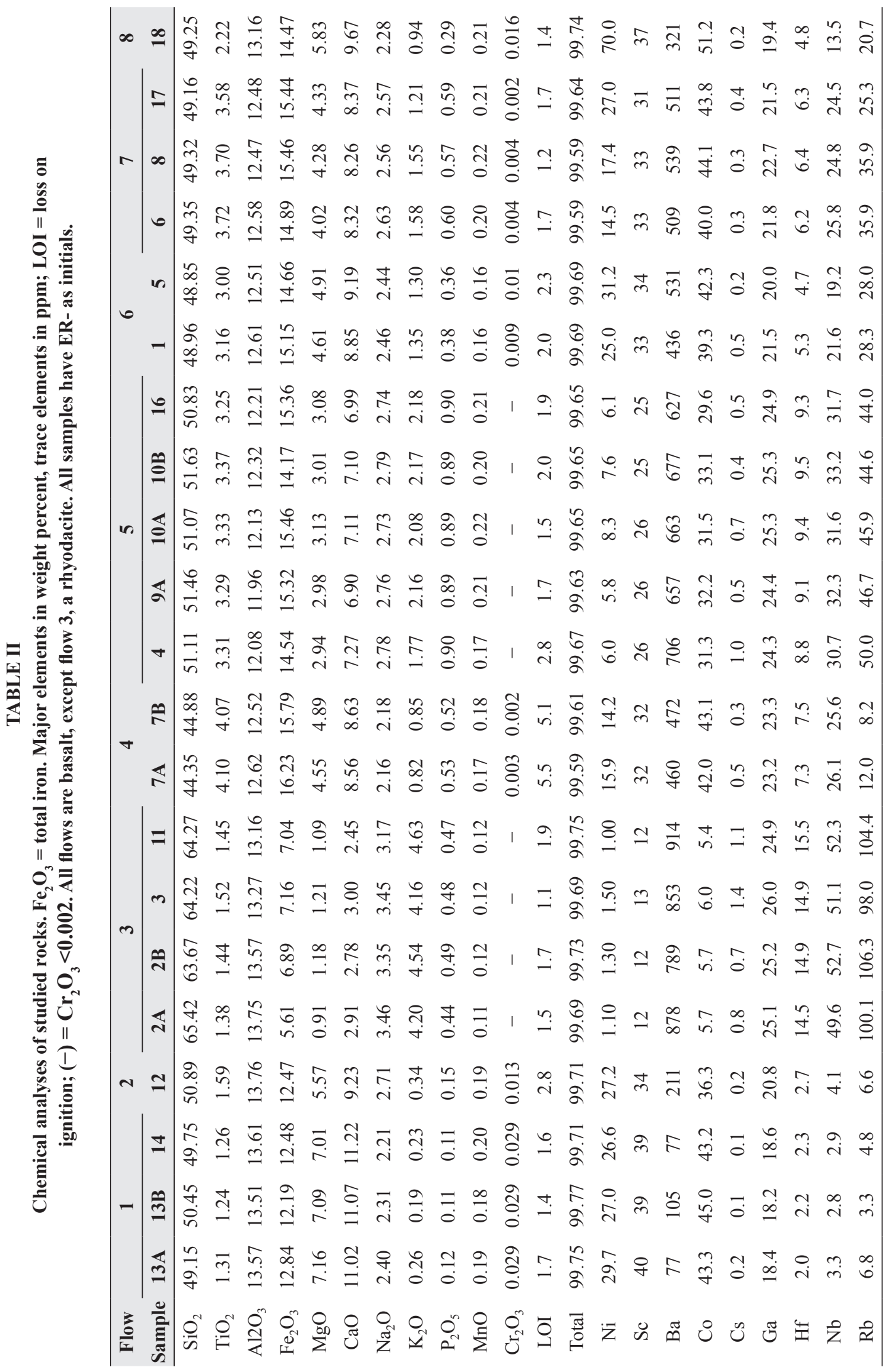




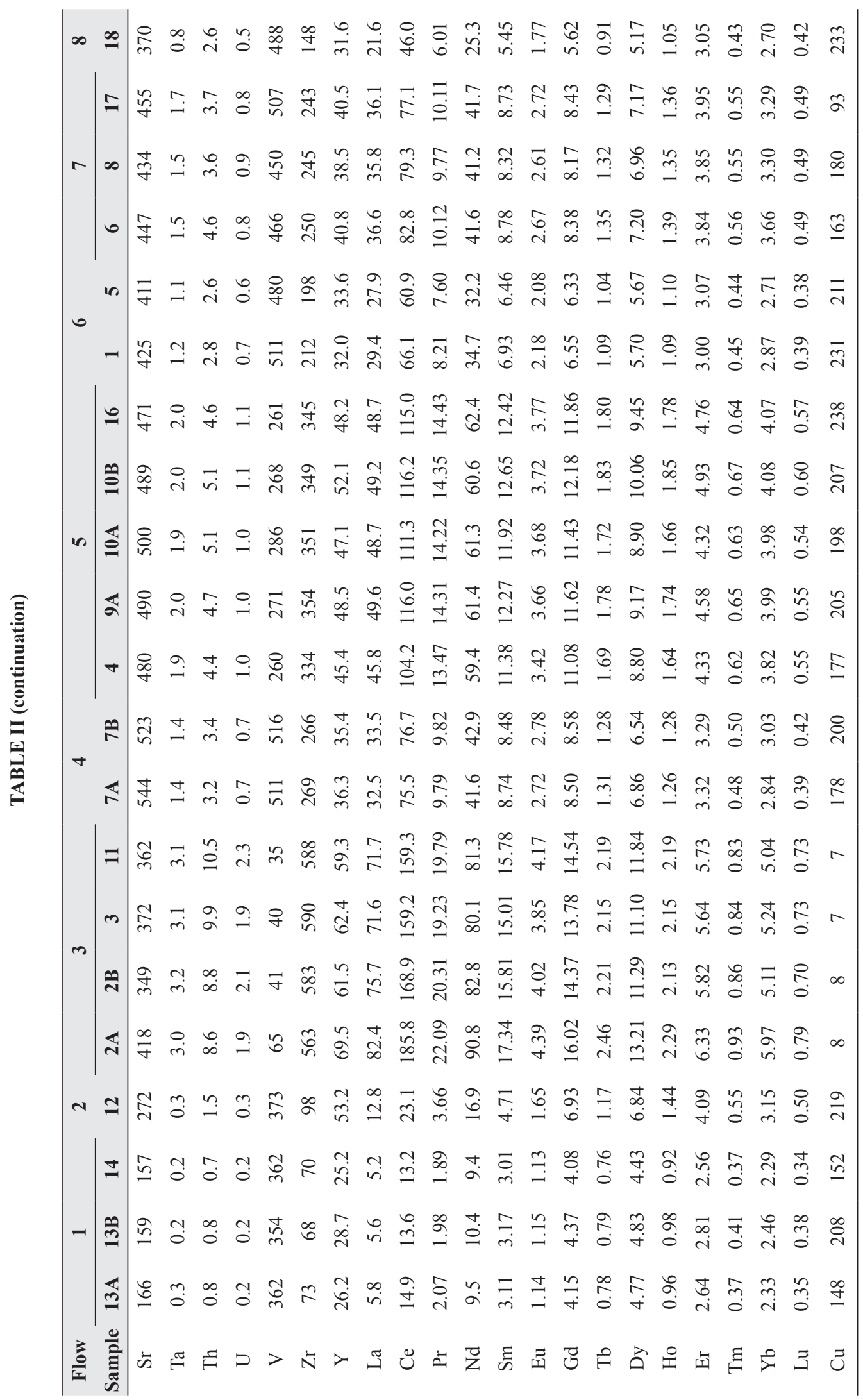


TABLE III

Location and elevation of analyzed samples. UTM coordinates, Datum SIRGAS2000.

\begin{tabular}{cccc}
\hline Samples & \multicolumn{2}{c}{ Coordinates } & Elevation \\
& East & North & a.s.1., $\mathrm{m}$ \\
\hline ER-1 & 342641 & 7044028 & 536 \\
ER-2 & 341594 & 7044199 & 463 \\
ER-3 & 342218 & 7043266 & 455 \\
ER-4 & 342947 & 7043146 & 512 \\
ER-5 & 343208 & 7043214 & 541 \\
ER-6 & 343425 & 7043187 & 566 \\
ER-7 & 345237 & 7043180 & 610 \\
ER-8 & 345403 & 7043976 & 639 \\
ER-9 & 345557 & 7044041 & 616 \\
ER-10 & 344404 & 7042809 & 573 \\
ER-11 & 341376 & 7047919 & 481 \\
ER-12 & 340335 & 7047489 & 410 \\
ER-13 & 340209 & 7047519 & 390 \\
ER-14 & 342181 & 7048250 & 436 \\
ER-16 & 343100 & 7046265 & 549 \\
ER-17 & 345641 & 7044263 & 668 \\
ER-18 & 345977 & 7044060 & 712 \\
\hline
\end{tabular}
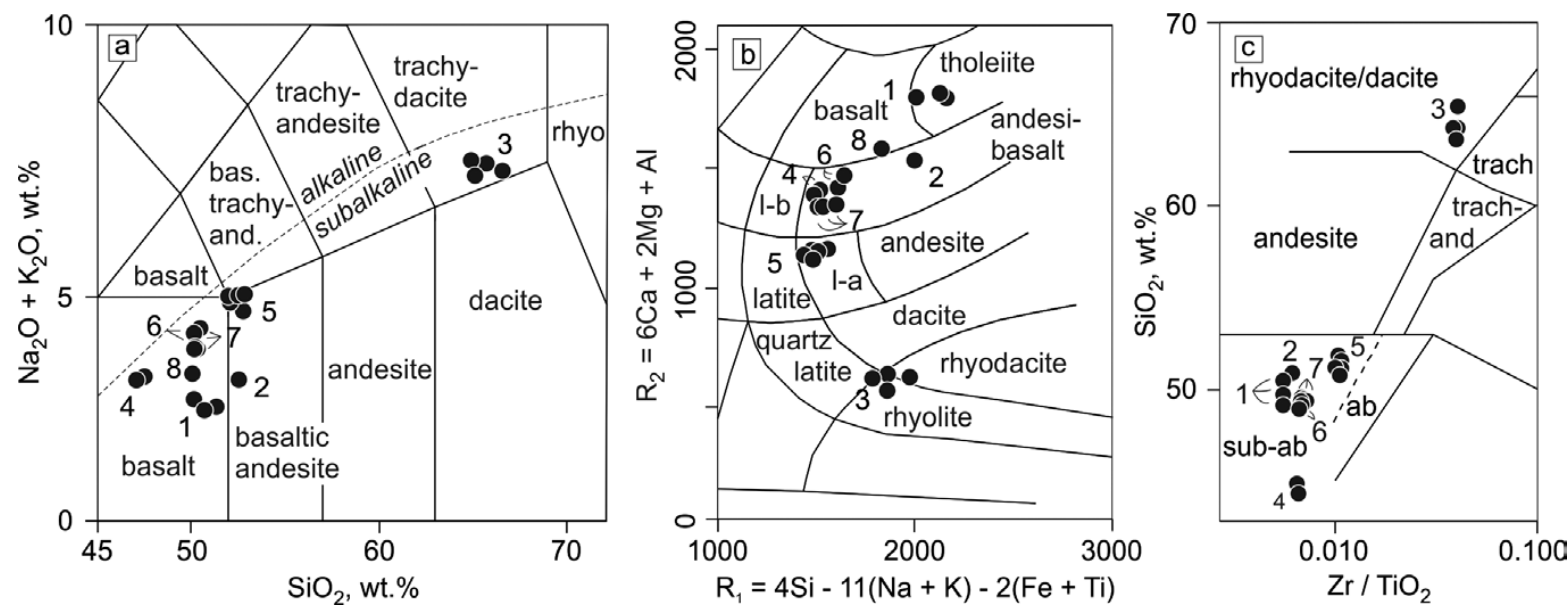

Figure 4 - Chemical classification of the eight lava flows from the Entre Rios mining district, based on (a) $\mathrm{Na}_{2} \mathrm{O}+\mathrm{K}_{2} \mathrm{O} \times \mathrm{SiO}_{2}$ (Le Bas et al. 1986), (b) R1 x R2 (De La Roche et al. 1980), (c) $\mathrm{Zr} / \mathrm{TiO}_{2}$ x SiO 2 (Winchester and Floyd 1977). Flow number indicated by number (e.g. 4). Abbreviations: bas. trachy-and. = basaltic trachyandesite, rhyo $=$ rhyolite, 1 -b $=1$ lati-basalt, $1-\mathrm{a}=$ lati-andesite, trach $=$ trachyte, trach-and $=$ trachy-andesite, $a b=$ alkaline basalt, sub-ab = subalkaline basalt.

characterize a silica gossan (Pertille et al. 2013) which is an important structure for the geological exploration of amethyst geodes. Silica gossans are present at the top of the uppermost flow.

The distribution of the lava flows in the mining district displays a marked structure of fault-blocks with downthrow to the west (Figs. 7, 8). This is similar to the structure identified by Rosenstengel and Hartmann (2012) in the Ametista do Sul mining district situated $300 \mathrm{~km}$ to the south. The faulting is usually interpreted as a consequence of the opening of the South Atlantic Ocean in the Cretaceous. 

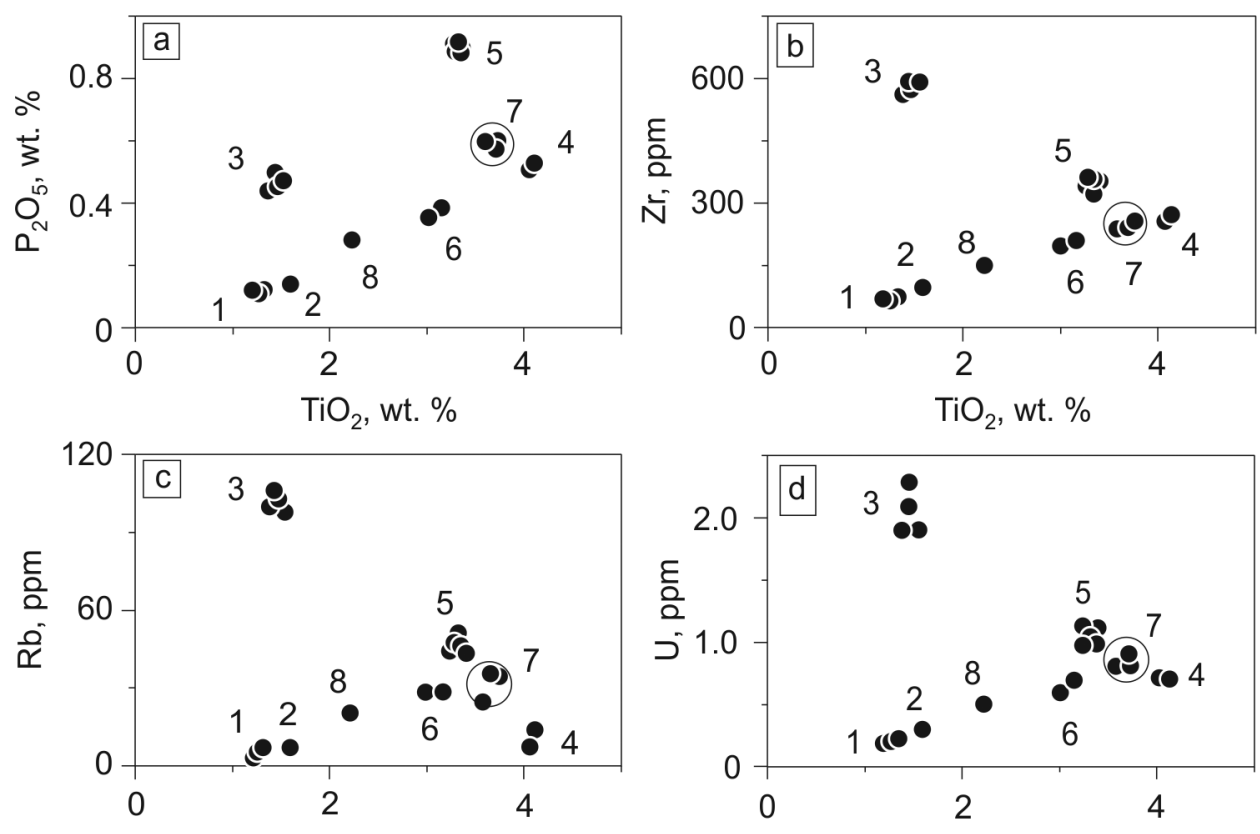

$\mathrm{TiO}_{2}$, wt. \%
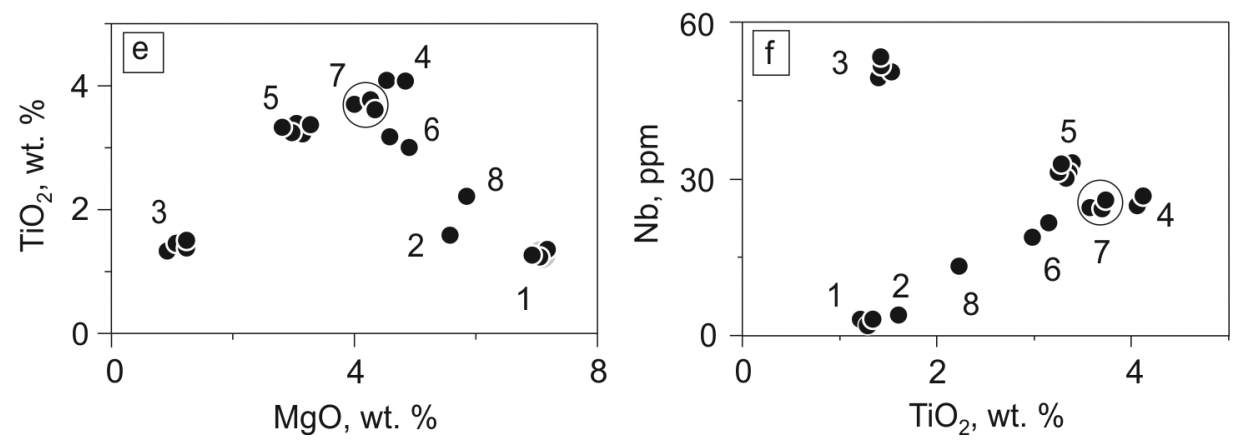

Figure 5 - (a)-(f) Chemical variation diagrams displaying the characteristic composition $\left(\mathrm{TiO}_{2}, \mathrm{MgO}, \mathrm{P}_{2} \mathrm{O}\right.$, $\mathrm{Zr}, \mathrm{Rb}, \mathrm{U}$ and $\left.\mathrm{Nb}\right)$ of each lava flow in the district.

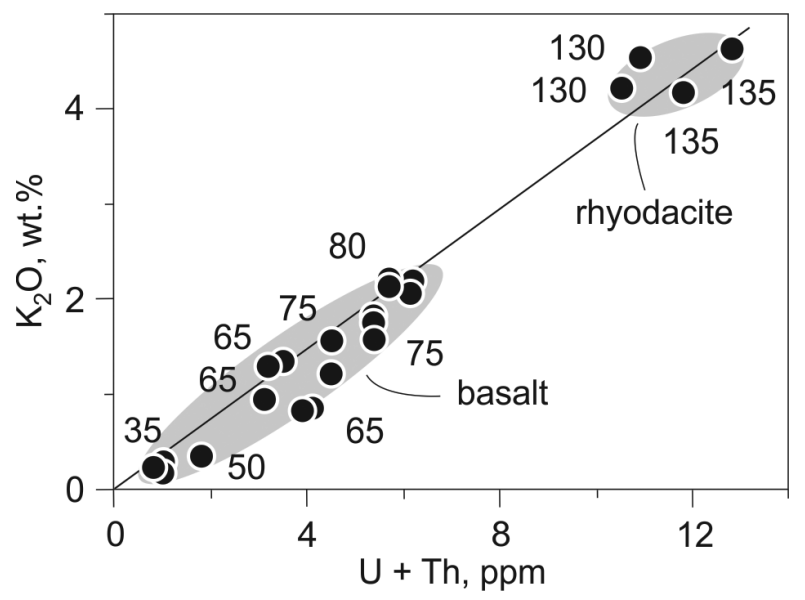

Figure 6 - Diagram displaying the positive correlation between the contents of $\mathrm{K}_{2} \mathrm{O}, \mathrm{U}$, Th and the gamma-ray emission rate. Cps values indicated (e.g., 75). 


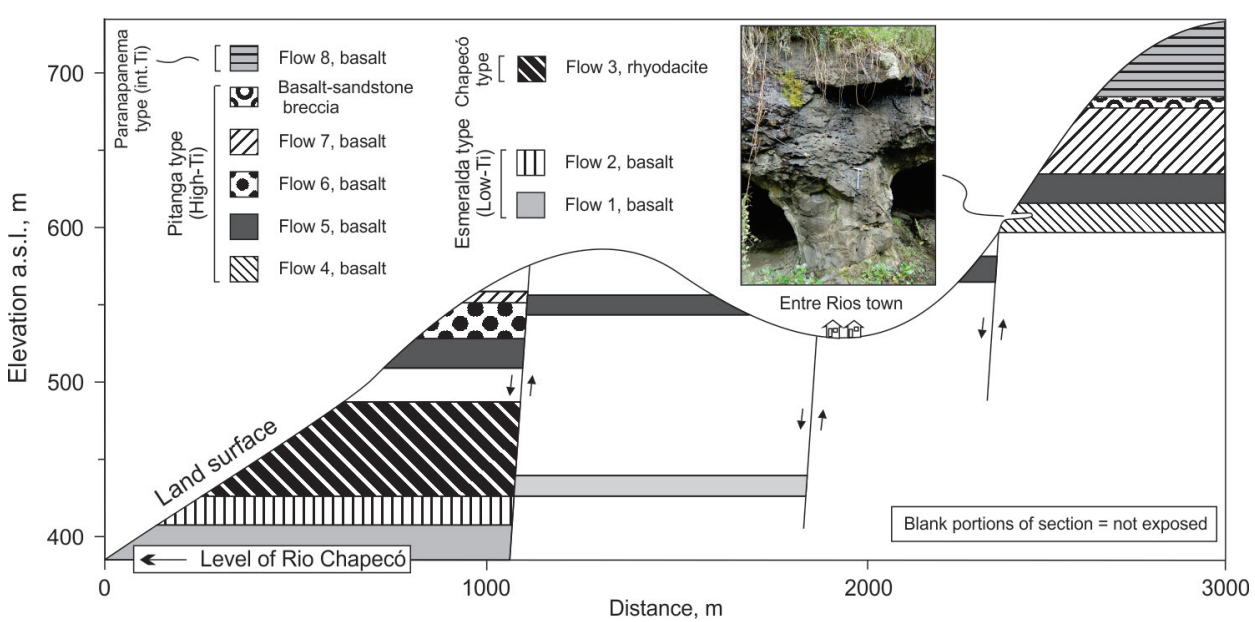

Figure 7 - Geological section of the Entre Rios mining district. Inset photo shows the entrance to underground mine.

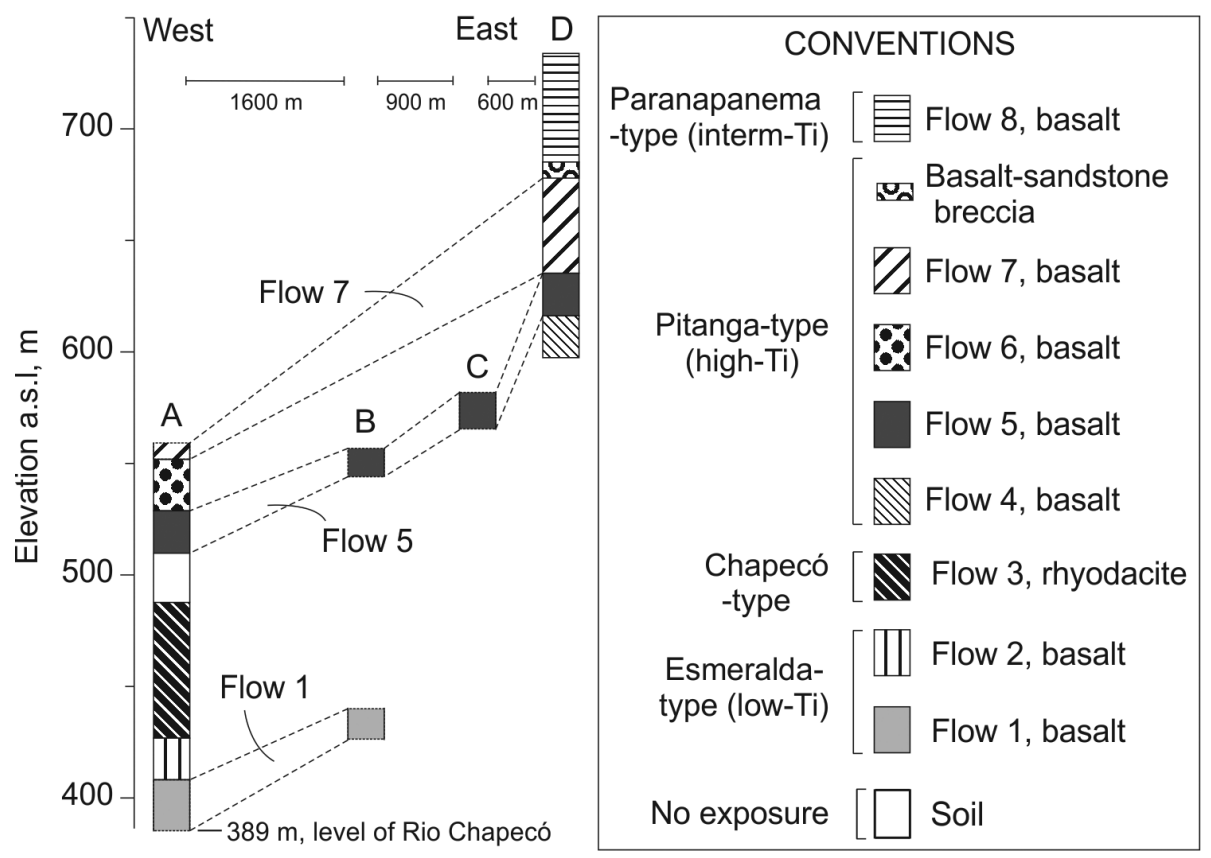

Figure 8 - Correlation chart of the lava flows in the Entre Rios mining district. Fault-block structures caused downthrow of the flows to the west.

\section{CONCLUSIONS}

Most significant conclusions are reached regarding the geological constraints of the amethyst geodes in the Entre Rios mining district. Among the eight flows present, only flows 4 and 5 are currently mined, but marked silica gossans occur at the top of the eighth flow. One rhyodacite occurs intercalated with seven basalt flows and these belong to the Esmeralda, Pitanga and Paranapanema chemical types. This is a result of intense variation in the mantellic and crustal processes responsible for the generation of the volcanism present in the district. The ore was generated by intense hydrothermal alteration of the basalts at low temperature, after 
the injection of sand from the deeply buried paleoerg. The distribution of the lava flows indicates a fault-block structure for the mining district, and this is of major significance in the search for additional deposits.

\section{ACKNOWLEDGMENTS}

Financial support for the study was provided by Programa de Apoio a Núcleos de Excelência (PRONEX)-Fundação de Amparo à Pesquisa do Estado do Rio Grande do Sul (FAPERGS)/ Conselho Nacional de Desenvolvimento Científico e Tecnológico (CNPq) on "Strategic minerals from southern Brazil" coordinated by the first author. The Geological Survey of Brazil Companhia de Pesquisa de Recursos Minerais (CPRM) allowed the use of a portable field gamma-spectrometer.

\section{RESUMO}

O distrito mineiro de Entre Rios produz um grande volume de geodos de ametista em minas subterrâneas e faz parte das jazidas de classe mundial da província vulcânica Paraná na América do Sul. Dois derrames de basalto são os produtores e têm números 4 e 5 na estratigrafia das lavas. Há sete derrames e um de riodacito no distrito. Na base da estratigrafia situada no leito do rio Chapecó, há dois derrames Esmeralda do tipo baixoTi. O terceiro derrame na sequência é um riodacito do tipo Chapecó, subtipo Guarapuava. Acima do derrame de riodacito, há 4 derrames de basalto Pitanga do tipo alto-Ti e que incluem os dois derrames mineralizados; somente o derrame do topo da estratigrafia é do tipo Paranapanema, médio-Ti. Cada derrame é identificado individualmente pelas suas propriedades geoquímicas e gama-espectrométricas. O estudo de várias seções no distrito levou à identificação de uma estrutura de blocos de falha. Os blocos estão alinhados NO, sendo que o bloco situado no lado oeste da falha foi rebaixado. Esta importante caracterização estrutural do distrito mineiro terá consequências significativas na busca de novas jazidas de geodos de ametista e no entendimento da evolução da província vulcânica Paraná.
Palavras-chave: geodo de ametista, distrito mineiro de Entre Rios, província vulcânica Paraná, geoquímica, gama-espectrometria.

\section{REFERENCES}

ARAÚJo LM, FranÇA AB AND PotTER PE. 1999. Hydrogeology of the Mercosul aquifer system in the Paraná and ChacoParaná Basins, South America, and comparison with the Navajo-Nugget aquifer system, USA. Hydrogeol Jour 7: 317-336.

ARIOLI EE, LICHT OAB, VASCONCELlos EMG, BONNET KL AND SANTOS EM. 2008. Faciologia vulcânica da Formação Serra Geral na região de Guarapuava, Paraná. IV Simpósio de Vulcanismo e Ambientes Associados, Foz do Iguaçu; Sociedade Brasileira de Geologia, Anais, 6 p.

Bellieni G, Vomin-Chiaramonti P, Marques LS, Melfi AJ, NARDY AJR, PICCIRILlo EM AND RoISENBERG A. 1984. High and Low $\mathrm{TiO}_{2}$ flood basalts from the Paraná plateau (Brazil): petrology and geochemical aspects bearing on their mantle origin. Neues Jahrb Mineral Petrol 150: 273-306.

COMmin-Fischer A, Berger G, Polvé M, Dubois M, SARdini P, BEAUfort D AND Formoso MLL. 2010. Petrography and chemistry of $\mathrm{SiO}_{2}$ filling phases in the amethyst geodes from the Serra Geral Formation deposit, Rio Grande do Sul, Brazil. Jour South Am Earth Sci 29: 751-760.

DE LA ROCHE H, LETERRIER J, GRANDCLAUdE P AND MARCHAL M. 1980. A classification of volcanic and plutonic rocks using $\mathrm{R}_{1}, \mathrm{R}_{2}$-diagrams and major element analysis - its relationships with current nomenclature. Chem Geol 29: 183-210.

DuARTe LC, Hartmann LA, Ronchi LH, Berner Z, THEYE T AND MASSONNE HJ. 2011. Stable isotope and mineralogical investigation of the genesis of amethyst geodes in the Los Catalanes gemological district, Uruguay, southernmost Paraná volcanic province. Mineralium Dep 46: 239-255.

DuARTE LC, HARTMANN LA, VASCONCEllos MAZ, MEDEIROS JTN AND THEYE T. 2009. Epigenetic formation of amethyst-bearing geodes from Los Catalanes gemological district, Artigas, Uruguay, southern Paraná Magmatic Province. Jour Volc Geoth Res 184: 427-436.

FrANK HT, GOMES MEB AND Formoso MLL. 2009. Review of the areal extent and the volume of the Serra Geral Formation, Paraná Basin, South America. Pesquisas Geociências (UFRGS) 36: 49-57.

Gilg HA, Morteani G, Kostitsyn Y, Preinfalk C, Gatter I AND STRIEDER AJ. 2003. Genesis of amethyst geodes in basaltic rocks of the Serra Geral Formation (Ametista do Sul, Rio Grande do Sul, Brazil): a fluid inclusion, REE, oxygen, carbon, and Sr isotope study on basalt, quartz, and calcite. Mineralium Dep 38: 1009-1025.

HARTMANN LA, ARENA KR AND DUARTE SK. 2012a. Geological relationships of basalts, andesites and sand injectites at the base of the Paraná volcanic province, Torres, Brazil. Jour Volc Geoth Res 237-238: 97-111. 
Hartmann LA, Arena KR, Duarte SK And Pertille J. 2012b. Long distance lava correlation in the Lower Cretaceous Paraná volcanic province along the Serra Geral cuesta, southeastern Brazil. Intern Jour Earth Sci 102: 1655-1669.

HARTMANn LA, BAGgio SB AND DUARTE SK. 2012c. Decoding geochemical and gamma-spectrometric signatures from lavas and sand injectites at the base of the Paraná volcanic province, Novo Hamburgo, Brazil. Intern Geol Rev 55: 510-524.

HARTMANN LA ET AL. 2012d. Sequential opening and filling of cavities forming vesicles, amygdales and giant amethyst geodes in lavas from the southern Paraná volcanic province, Brazil and Uruguay. Intern Geol Rev 54: 1-14.

Hartmann LA, Duarte SK and Pertille J. 2010a. Roteiro de Campo. Geologia dos geodos de ametista de Quaraí, Brasil - Uma imersão no vulcanismo, hidrotermalismo e na exploração mineral no Grupo Serra Geral. Porto Alegre, Gráfica da UFRGS, p. 13-71.

Hartmann LA, Wildner W, DuARTe LC, DuARTE SK, Pertille J, ARENA KR, Martins LC AND Dias NL. 2010b. Geochemical and scintillometric characterization and correlation of amethyst geode-bearing Paraná lavas from the Quaraí and Los Catalanes districts, Brazil and Uruguay. Geol Mag 147: 954-970.

Hurst A, Scott A And Vigorito M. 2011. Physical characteristics of sand injectites. Earth-Sci Rev 106: 215-246.

JACQUES PD, MACHADO R AND NUMMER AR. 2010. Lineamentos estruturais na borda leste da Bacia do Paraná em Santa Catarina: análise multiescala com base em imagens LANDSAT e SRTM. Pesquisas Geociências (UFRGS) 37: 117-131

JANASI VA, FREITAS VA AND HEAMAN LH. 2011. The onset of flood volcanism, Northern Paraná Basin, Brazil: A precise $\mathrm{U}-\mathrm{Pb}$ baddeleyite/zircon age for a Chapecó-type dacite. Earth Planet Sci Lett 302: 147-153.

Juchem PL, Chodur NL AND LicCARdo A. 2010. Depósitos de ametista em Santa Catarina, sul do Brasil. In: $45^{\circ}$ Congresso Brasileiro de Geologia, Belém, 1 p.

LE BAS MJ, LE MAITRE RW, STRECKEISEN A, ZANETTIN B AND Iugs Sub COMMISSION ON THE SYSTEMATIC OF IGNEOUS RoCKS. 1986. A chemical classification of volcanic rocks based on the total alkali-silica diagram. Jour Petrol 27: $745-750$
Morteani G, Kostitsyn Y, Preinfalk C And GILG HA. 2010. The genesis of the amethyst geodes at Artigas (Uruguay) and the paleohydrology of the Guaraní aquifer: structural, geochemical, oxygen, carbon, strontium isotope and fluid inclusion study. Intern Jour Earth Sci 99: 927-947.

NARDY AJR, MACHADO FB AND OLIVEIRA MAF. 2008. As rochas vulcânicas mesozóicas ácidas da Bacia do Paraná: litoestratigrafia e considerações geoquímicoestratigráficas. Rev Bras Geocien 38: 178-195.

Peate DW, Hawkesworth CJ AND Mantovani MSM. 1992. Chemical stratigraphy of Paraná lavas (South America): classification of magma types and their spatial distribution. Bull Volc 55: 119-139.

Pertille J, Hartmann LA, Duarte SK, Arena KR, Rosa MLCC AND BARBOZA EG. 2013. Gossan characterization in the Quaraí and Los Catalanes amethyst geode districts (Brazil and Uruguay), Paraná volcanic province, using rock geochemistry and gamma-spectrometry. Jour Geoch Expl 124: 127-139.

PINTO VM AND HARTMANN LA. 2011. Flow-by-flow chemical stratigraphy and evolution of thirteen Serra Geral Group basalt flows from Vista Alegre, southernmost Brazil. An Acad Bras Cienc 83: 425-440.

Pinto VM, Hartmann LA, SANTOS JOS, MCNAUGHTON NJ AND WILDNER W. 2011. Zircon U-Pb geochronology from the Paraná bimodal volcanic province support a brief eruptive cycle at $\sim 135 \mathrm{Ma}$. Chem Geol 281: 93-102.

Proust D AND Fontaine C. 2007. Amethyst-bearing lava flows in the Paraná basin (Rio Grande do Sul, Brazil): cooling, vesiculation and formation of the geodic cavities. Geol Mag 144: 53-65.

Rosenstengel LM AND HARTMANN LA. 2012. Geochemical stratigraphy of lavas and fault-block structures in the Ametista do Sul geode mining district, Paraná volcanic province, southern Brazil. Ore Geol Rev 48: 332-348.

WINCHESTER JA AND FLOYD PA. 1977. Geochemical discrimination of different magma series and their differentiation products using immobile elements. Chem Geol 20: 325-343.

ZALÁN PV, WOLFF S, ASTOLFII MAM, VIEIRA IS, CONCEIÇÃO JCJ, APPI VT, Neto EVS, CERQueIRA JR AND MARQUES A. 1991. The Paraná Basin, Brazil. In: Leighton MW, Kolata DR, Oltz DF and Eidel JJ (Eds), Interior Cratonic Basins. AAPG Mem 51: 681-708. 